\title{
Antiprogesterone Compound, RU486 Administration to Terminate Pregnancy in Dogs and Cats
}

Tadashi SANKAI*, Tuyoshi ENDO, Kiichi KANAYAMA, Yuzi SAKUMA, Motoaki UMEZU ${ }^{1)}$, and Junji MASAKI ${ }^{1)}$

Department of Veterinary Physiology, College of Agriculture and Veterinary Medicine, Nihon University, 1866 Kameino, Fujisawa, Kanagawa 252, and "Laboratory of Animal Reproduction, Faculty of Agriculture, Tohoku University, 1-1 Amamiya Tsutsumidori, Aoba-ku Sendai, Miyagi 981 Japan

(Received 5 February 1991/Accepted 23 July 1991)

J. Vet. Med. Sci. 53(6): 1069-1070, 1991

KEY WORDS: cat, dog, RU486.

In the clinical treatment of small animals such as dogs and cats, it is useful to establish the method of termination of pregnancy. Pregnancy can be terminated by estrogen $[2,9,13]$, prostaglandin $F_{2 \alpha}[16]$, or prolactin inhibitor $[10,16]$. However, these drugs produce the various side effects such as bone marrow suppression, pyometra, emesis and loose stools. Non-surgical procedure for artificial abortion by using such drugs is not always effective through the pregnancy period.

The synthetic steroid RU486, the antiprogesterone developed by Roussel-UCLF in France, is known to bind with progesterone receptors. It induces the termination of pregnancy, due to a strongly antagonistic influence on progesterone $[5-8,11,15]$.

In the investigation that the effect of RU486 on progestational activity in dogs, Concannon et al. [3, 4] administered $2.5 \mathrm{mg} / \mathrm{kg}$ of RU486 orally, twice a day, for 4.5 days starting at day-32 of pregnancy. The dogs aborted without any side effects. The present experiment was undertaken to examine the effect of RU486 for abortion on the various stage of pregnancy in dogs and cats.

Pregnant dogs and cats were administered RU486. The breeds of dogs were three mongrel, two Maltese, one Shiba, one Akita and one Shikoku; the cats were five mongrel and one Siamese. Mating was confirmed in the dogs administered RU486 at early and middle stages of pregnancy and in the cats administered at middle and late stages of pregnancy. Pregnancy was determined for animals administered RU486 at the middle, late and final stages by radiography, ausculation or palpation. For those animals, body temperature, pulse rate, and respiration rate were examined before and after administration. The eight dogs and five cats were administered a single subcutaneous injection of RU486 which had been dissolved in sesame oil to make a $20 \mathrm{mg} / \mathrm{m} l$ solution. One cat was orally administered a tablet preparation of RU486. The animals were closely observed thereafter.

The effects of RU486 in the eight pregnant dogs are shown in Table 1 . They were clinically normal before the treatment. As shown in Table 1, RU486 induced the termination of pregnancy in five dogs administered RU486 of 20 to $22.7 \mathrm{mg} / \mathrm{kg} \mathrm{B}$.W., and in one dog of the three administered RU486 of $10 \mathrm{mg} / \mathrm{kg} \mathrm{B}$.W. Two Maltese and one Shiba which were administered RU486 of $20 \mathrm{mg} / \mathrm{kg}$ B.W. by subcutaneous injection at the middle stage discharged fetal membranes. One mongrel of the three at the late stage delivered immature fetuses. Two mongrel dogs administered RU486 of $10 \mathrm{mg} / \mathrm{kg} \mathrm{B.W}$. at the final stage of pregnancy delivered 5 and 7 puppies at 28 to 73 hours and 27 to 45 hours respectively after the administration of RU486. All of them were clinically normal.

As a result, the abortive effect of RU486 when administered subcutaneously to the dogs, at the early, middle and late stages of pregnancy was determined. It was not clear whether RU486 induced the delivery of the dogs administered at the final stage. However, as RU486

Table 1. Effects of RU486 administration on termination of pregnancy in dogs

\begin{tabular}{|c|c|c|c|c|c|c|}
\hline No. & Breed & $\begin{array}{l}\text { Body weight } \\
(\mathrm{kg})\end{array}$ & $\begin{array}{l}\text { Dose of } \\
\text { RU486 } \\
(\mathrm{mg} / \mathrm{kg})\end{array}$ & $\begin{array}{c}\text { Time of } \\
\text { administration } \\
\text { (Days after mating) }\end{array}$ & $\begin{array}{l}\text { Termination } \\
\text { of pregnancy }\end{array}$ & $\begin{array}{l}\text { Observation of fetal } \\
\text { membrane discharge }\end{array}$ \\
\hline 401 & mongrel & 9.5 & 10.0 & $-(\mathrm{L})$ & Yes & $\mathrm{No}^{b)}$ \\
\hline 402 & "1 & 12.0 & 10.0 & $-(\mathrm{F})$ & No: Delivered 27 hrs later ${ }^{\text {a) }}$ & No \\
\hline 403 & $"$ & 12.0 & 10.0 & $-(\mathrm{F})$ & No: Delivered 28 hrs later & No \\
\hline 404 & Maltese & 3.1 & 20.0 & $28(\mathrm{M})$ & Yes & Yes: 29 hrs later \\
\hline 405 & " & 4.0 & 20.0 & $35(\mathrm{M})$ & Yes & Yes: 31 hrs later \\
\hline 406 & Shiba & 7.0 & 20.0 & $27(\mathrm{M})$ & Yes & Yes: 45 hrs later \\
\hline 407 & Akita & 24.0 & 20.8 & $24(\mathrm{M})$ & Yes & No \\
\hline 408 & Shikoku & 15.0 & 22.7 & $11(\mathrm{E})$ & Yes & No \\
\hline
\end{tabular}

E: Early stage ( $\sim 20$ days) M: Middle stage (21 40 days) L: Late stage ( $41 \sim 55$ days) F: Final stage (56 days)

a) Body temperature dropped shortly before delivery.

b) Delivered immature fetuses 65 hrs after RU486 injection.

\footnotetext{
* Correspondence to: Sankal, T., Tsukuba Primate Center for Medical Science, The National Institute of Health, Hachimandai, Tsukuba 305, Japan.
} 
Table 2. Effects of RU486 administration on termination of pregnancy in cats

\begin{tabular}{lcccccc}
\hline No. & Breed & $\begin{array}{c}\text { Body weight } \\
(\mathrm{kg})\end{array}$ & $\begin{array}{c}\text { Dose of } \\
\text { RU486 } \\
(\mathrm{mg} / \mathrm{kg})\end{array}$ & $\begin{array}{c}\text { Time of } \\
\text { administration } \\
\text { (Days after mating) }\end{array}$ & $\begin{array}{c}\text { Termination } \\
\text { of pregnancy }\end{array}$ & $\begin{array}{c}\text { Observation of fetal } \\
\text { membrane discharge }\end{array}$ \\
\hline 501 & Siamese & 4.2 & 23.8 & $40(\mathrm{~L})$ & Yes & Yes: 72 hrs later \\
501 & $"$ & 3.5 & 34.3 & $30(\mathrm{M})$ & Yes & Yes: 72 hrs later \\
502 & mongrel & 4.5 & 20.0 & $-(\mathrm{F})$ & No: Delivered 94 hrs later $)$ & No \\
503 & $\prime \prime$ & 4.2 & 20.0 & $43(\mathrm{~L})$ & No: Hysterotomy 90 hrs later & No \\
504 & $"$ & 4.5 & 26.7 & $45(\mathrm{~L})$ & No: Hysterotomy 79 hrs later & No \\
505 & $"$ & 3.7 & 32.4 & $46(\mathrm{~L})$ & No & No \\
$506^{\text {a) }}$ & $"$ & 3.7 & 27.0 & $-(\mathrm{F})$ & No: Delivered 6 days later & No \\
\hline
\end{tabular}

E: Early stage ( $\sim 20$ days) M: Middle stage (21 40 days) L: Late stage (41 55 days) F: Final stage (56 days)

a) Tablet preparation of RU486 was orally administered.

b) Body temperature dropped shortly before delivery.

is known to induce the delivery in rats [1], it is quite likely to induce the delivery in dogs through this experiment.

The effects of RU486 in the six pregnant cats are shown in Table 2. They were clinically normal before the treatment. Pregnancy was terminated in a Siamese cat only. In this cat three pregnancies were observed during this study. At the late stage of the first pregnancy and the middle stage of the second pregnancy, the cat was administered a subcutaneous injection of RU486, resulting in the termination of pregnancy. When the cat became pregnant for the third time, the fetuses and uterus were removed by laparotomy approximately 50 days after mating. The other five cats were not terminated the pregnancy in spite of the administration of RU486. However, two cats administered RU486 at the final stage of pregnancy delivered. RU486 may have the effect of the induced delivery.

Administration of RU486 in cats was not so effective as in the dogs. As the pregnancy of one Siamese was terminated by RU486, it may have the some effect in the cats. The cat underwent another pregnancy after the termination of the first pregnancy. The second pregnancy was again terminated by RU486. The cat became pregnant once again thereafter. These results correspond with those in rats [14] and rabbits [12] in which RU486 had no adverse effects in the reproductive ability after the termination of pregnancy.

Administration of RU486 had no side effects including the clinical findings through this experimental period both in dogs and cats.

It was thus shown that antiprogesterone compound, RU486 was effective in the termination of pregnancy in the dogs. It had no adverse effects of further reproductive ability. Though it was partly demonstrated to terminate the pregnancy by using RU486 in cats, further studies such as appropriate time and dose of administration are needed.

ACKNOWLEDGEMENTS. The authors would like to thank Roussel-UCLF, Paris, France for supply of the RU486 compound. We wish also to express our gratitude to Drs. H. Arai, A. Sakanashi, T. Fukazawa, Z. Uemura, M. Iwamoto and S. Yamashita for support in this study.

REFERENCES

1. Bosc, M. J., Germain, G., Nicolle, A., Mouren, M., Philibert, D., and Baulieu, E. E. 1987. J. Reprod. Fertil. 79: $1-8$.

2. Bowen, R. A., Olson, P. N., Young, S., and Withrow, S. J. 1988. Am. J. Vet. Res. 49: 27-31.

3. Concannon, P. W., Dillingham, L., and Spitz, I. M. 1988. Acta Endocrinol. (Co.) 118: 389-398.

4. Concannon P. W., Yeager, A., Frank, D., and Iyampillai, A. 1990. J. Reprod. Fertil. 88: 99-104.

5. Endo, T., Sankai, T., Kanayama, K., and Sakuma, Y. 1988. Adv. Contraception 4: 24.

6. Grimes, D. A., Mishell, D. R. Jr., Shope, D., and Lacarra, M. 1988. Am. J. Obstet. Gynecol. 158: 1307-1312.

7. Hodgen, G. D. 1985. Fertil. Steril. 44: 263-267.

8. Nieman, L. K., Choate, T. M., Chrousos, G. P., Healy, D. L., Morin, M., Renquist, D., Merriam, G. R., Spitz, I. M., Bardin, C. W., Baulieu, E. E., and Loriaux, D. L. 1987. New Engl. J. Med. 316: 187-191.

9. Olsen, P. N., Nett, T. M., Bowen, R. A., Amann, R. P., Sawyer, H. R., Gorell, T. A., Niswender, G. D., Pickett, R. W., and Phemister, R. D. 1986. Compend. Contin. Educ. Pract. Vet. 8: 235-240.

10. Post, K., Evans, L. E., and Jochle, W. 1988. Theriogenology 29: 1233-1243.

11. Sankai, T., Kanayama, K., Endo, T., and Sakuma, Y. 1988. Adv. Contraception 4: 25.

12. Sankai, T., Kanayama, K., Endo, T., Sakuma, Y., Umezu, M., and Masaki, J. 1991. Jpn. J. Fertil. Steril. 36: 211-215 (in Japanese).

13. Schalm, O. W. 1978. Canine Pract. 5: 57-61.

14. Umezu, M., Tadano, M., Furusawa, T., Ishii, S., Masaki, J., Sankai, T., Endo, T., and Sakuma, Y. 1988. Jpn. J. Fertil. Steril. 33: 431-437.

15. Vervest, H. A. M. and Haspels, A. A. 1985. Fertil. Steril. 44: 627-632.

16. Wichtel, J. J., Whitacre, D. J., and Van Camp, S. D. 1990. Theriogenology 33: 829-836. 